\title{
Changes in Glomerular Filtration Rate and Its Relation to Serum Calcium Level in Advanced Stages of Chronic Kidney Disease
}

\author{
Gobinda Chandra Saha1 ${ }^{1}$, M Akhtaruzzaman², Ekramul Mustafa ${ }^{3}$, Asif Mahmud $^{4}$, \\ Sunil Kumar Sikder ${ }^{5}$ \\ ${ }^{1}$ Associate Professor, Department of Physiology, Sher-E-Bangla Medical College, Barisal, Bangladesh; \\ ${ }^{2}$ Associate Professor, Department of Biochemistry, National Institute of Neuroscience \& Hospital, \\ Dhaka, Bangladesh; ${ }^{3}$ Lecturer, Department of Physiology, Dhaka Medical College, \\ Dhaka, Bangladesh; ${ }^{4}$ Lecturer, Department of Pharmacology, Dr. Sirajul Islam \\ Medical College, Dhaka, Bangladesh; ${ }^{5}$ Assistant Professor, Department of \\ Oncology, Faridpur Medical College, Faridpur, Bangladesh
}

Received on: 24 July 2014; Reviewed on: 26 September 2014; Published on: 1 January 2015

\begin{abstract}
Background: The progression of CKD occurs in five different stages in which there are gradual changes of GFR, serum creatinine and serum calcium. Objective: The study was undertaken to determine GFR in advanced stages of CKD and its relation with s. creatinine and s. calcium and also to find out the correlation between s. creatinine and s. calcium. Methodology: This study was carried out in the departments of Physiology and Nephrology, Rajshahi Medical College. All the advanced stage chronic kidney disease patients were taken as comparison. Apparently healthy persons were taken as control. Serum Creatinine was measured by alkaline picrate method; estimation of GFR was done by using Cockcroft- Gault formula and serum calcium was performed by analyzer. Result: In this study a total number of 120 subjects were included, out of which 30 were healthy control and 90 were diagnosed cases of advanced stages of CKD. Among the patients, $55(61.12 \%)$ were male and $35(38.88 \%)$ were female. Mean age $( \pm \mathrm{SD})$ of the patients were $45 \pm 11.16$ (Range 20-65 years). While comparing between groups of CKD patients, it was found that $\mathrm{s}$. creatinine of control group was significantly lower than that of group 1. Again s. creatinine of Group 1 was significantly lower than that of group 2 and similarly, s. creatinine of group 2 was significantly lower than that of group 3. On the other hand, s. calcium of control group was significantly higher than group 1 , likewise s. calcium of group 1 was significantly higher than that of group 2 and s. calcium of group 2 was significantly higher than that of group 3. Conclusion: From this study the inference could be drawn that serum calcium had a positive correlation with GFR and a negative correlation with s. creatinine. [J Natl Inst Neurosci Bangladesh $2015 ; 1(1): 15-17]$
\end{abstract}

Keywords: CKD, GFR, serum creatinine, serum calcium

Corresponding author: Dr. Gobinda Chandra Saha, Associate Professor, Dept. of Physiology, Sher-E-Bangla Medical College, Barisal, Bangladesh; Email: dr.gobinda.saha@gmail.com; Cell no.: +8801714090836;

Conflict of interest: No conflict of interest with any of the authors.

Funding of the study: None

Contribution of the authors: GCS \& MA: Substantial contributions to conception of research work, design and protocol development, Acquisition of data, analysis and interpretation of data. Also drafting the article and revising it critically for important intellectual content; and final approval of the version to be published. EM, AM \& SKS:: Acquisition of data, analysis and interpretation of data. Also drafting the article and revising it critically for important intellectual content; and final approval of the version to be published.

How to cite this article: Saha GC, Akhtaruzzaman M, Mustafa E, Mahmud A, Sikder SK. Study on Changes in Glomerular Filtration Rate (GFR) and Its Relation to Serum Calcium Level in Advanced Stages of Chronic Kidney Disease. J Natl Inst Neurosci Bangladesh 2015; 1(1):15-17

\section{Introduction}

Chronic kidney disease (CKD) is a progressive loss of renal function over a period of months or years through five stages. Each stage is a progression through an abnormally low and deteriorating glomerular filtration rate, which is usually determined indirectly by the serum creatinine level ${ }^{1}$. As the kidney undergoes progressive changes from early stage up to advanced stages (Stage 4,5) kidney function is deteriorating so Calcitriol (1,25 dihydroxy cholicalciferol) level will be decreased. As a result calcium absorption from
GIT is reduced. Thus there is development of hypocalcaemia. Inorganic phosphate does not excrete through kidney as a result serum inorganic phosphate level will increase. Creatinine clearance rate provides the most helpful clinical index of GFR ${ }^{3}$ and GFR is the most widely used test of renal function ${ }^{4-5}$. Creatinine clearance rate $(\mathrm{CCr})$ is the volume of blood plasma that is cleared of Creatinine per unit time and is a useful measure for approximating the GFR. Both GFR and CCr can be accurately calculated by comparative measurement of substances in the blood and 
urine or estimated by formulas using just a blood test result (eGFR and eCCr). The present study was undertaken to determine GFR in advanced stages of CKD and its relation with serum creatinine and serum calcium and also to find out the correlation between serum creatinine and serum calcium.

\section{Methodology}

This study was designed as comparative cross-sectional study and was carried out in the departments of Physiology and Nephrology at Rajshahi Medical College, Rajshahi, Bangladesh. Patients of advanced stages (stages 3 to 5) of CKD, with age ranged from 20-65 years were including as study populstion. Apparently healthy persons of same age ranges were taken as controls of the study. On the basis of KDOQI clinical practice guidelines stratification ${ }^{2}$ patients were divided into 3 groups which were CKD3, CKD4 and CKD5 on the basis of their eGFR values from. Patients was on group CKD3 having GFR of $30-59 \mathrm{ml} / \mathrm{min} / 1.73 \mathrm{~m}^{2}$. CKD4 and CKD5 group also had patients having GFR 1529 and $<15$ respectively. The following formula ${ }^{3}$ was used for calculating the values,

$$
\begin{aligned}
\mathrm{eCCr}= & \frac{(140-\mathrm{AGE}) \mathrm{X} \text { Mass (in KG) } \mathrm{X}[0.85 \text { if Female }]}{72 \mathrm{X} \text { serum Creatinine (in mg/dl) }} \\
& (\text { Cockcroft DW, Gault HM et al,1976) }
\end{aligned}
$$

Serum Creatinine was measured by alkaline picrate method; estimation of GFR was done by using Cockcroft-Gault formula $^{3}$ and serum calcium was performed by analyzer (ScreenMaster-3000).

\section{Results}

A total number of 90 patients were recruited in this study of which 55 patients were male and the rest 35 patients were female. Mean \pm SD of S. Creatinine in healthy control was $0.936 \pm 0.116 \mathrm{mg} / \mathrm{dl}$ and mean of serum creatinine was $2.226 \pm 0.272,3.698 \pm 0.915 \& 6.906 \pm 2.439$ in CKD3, CKD4 \& CKD5 respectively (Table I).

When serum creatinine level compared between groups, control group was significantly lower than CKD3 group $(\mathrm{P}<0.05), \mathrm{CKD} 3$ group was significantly lower than CKD4 group $(\mathrm{P}<0.05)$ and $\mathrm{CKD} 4$ group was significantly lower than CKD5 group $(\mathrm{P}<0.05)$ [Figure 1]. Mean $\pm \mathrm{SD}$ of GFR

Table 1: Different biochemical parameters in various groups (Mean $\pm \mathrm{SD})$

\begin{tabular}{lllll}
\hline $\begin{array}{l}\text { Biochemical } \\
\text { parameters }\end{array}$ & $\begin{array}{l}\text { Control } \\
\text { group } \\
(\mathrm{n}=30)\end{array}$ & $\begin{array}{l}\text { CKD3 } \\
\text { group } \\
\mathrm{n}=30)\end{array}$ & $\begin{array}{l}\text { CKD4 } \\
\text { group } \\
\mathrm{n}=30)\end{array}$ & $\begin{array}{l}\text { CKD5 } \\
\text { group } \\
\mathrm{n}=30)\end{array}$ \\
\hline Serum & $0.936 \pm$ & $2.226 \pm$ & $3.698 \pm 6.90 \pm$ \\
Creatinine & 0.116 & 0.272 & 0.915 & 2.439 \\
GFR & $104.99 \pm$ & $36.25 \pm$ & $21.14 \pm$ & $10.30 \pm$ \\
& 16.66 & 5.58 & 5.42 & 2.69 \\
Serum & $2.33 \pm$ & $1.76 \pm$ & $1.52 \pm$ & $1.04 \pm$ \\
Calcium & 0.20 & 0.11 & 0.14 & 0.05 \\
\hline
\end{tabular}

in healthy control was $104.953 \pm 16.663$, mean GFR in CKD3 group was $36.256 \pm 5.582$, mean GFR in CKD4 group was $21.142 \pm 5.420$ and mean GFR in CKD5 group was $10.304 \pm 2.694$ (Table III).

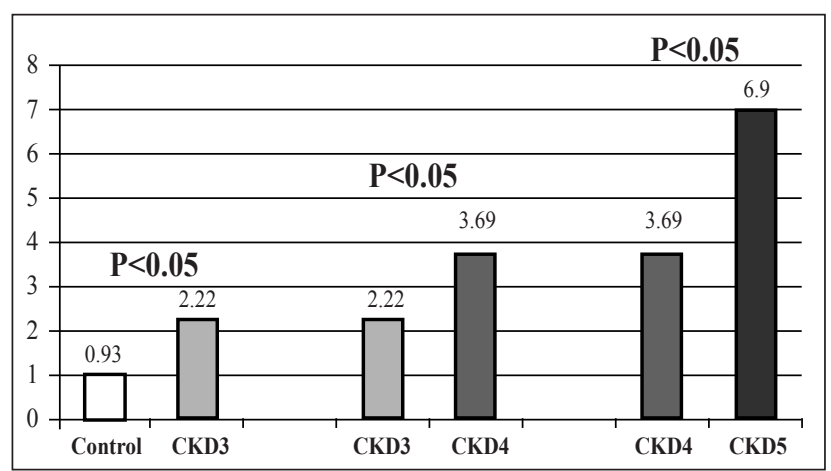

Figure 1: Comparison of serum creatinine among different groups

When GFR was compared between groups, control group was significantly higher than $\mathrm{CKD}^{3}$ group $(\mathrm{P}<0.05), \mathrm{CKD} 3$ group was significantly higher than $\mathrm{CKD} 4$ group $(\mathrm{P}<0.05)$ and CKD4 group was significantly higher than CKD5 group $(\mathrm{P}<0.05)$. The mean $\pm \mathrm{SD}$ serum calcium level in healthy control group was $2.330 \pm 0.203 \mathrm{mmol} / \mathrm{L}$, mean s. calcium in CKD3 group was $1.762 \pm 0.113 \mathrm{mmol} / \mathrm{L}$, mean s. calcium in CKD4 group was $1.527 \pm 0.144 \mathrm{mmol} / \mathrm{L}$, mean s. calcium in CKD5 group was $1.042 \pm 0.051 \mathrm{mmol} / \mathrm{L}$ (Table III). When s. calcium levels were compared between the groups, control group was significantly higher than CKD3 group $(\mathrm{P}<0.05), \mathrm{CKD} 3$ group was significantly higher than CKD4 group $(\mathrm{P}<0.05)$ and $\mathrm{CKD} 4$ group was significantly higher than $\mathrm{CKD} 5$ group $(\mathrm{P}<0.05)$ [Figure 2].

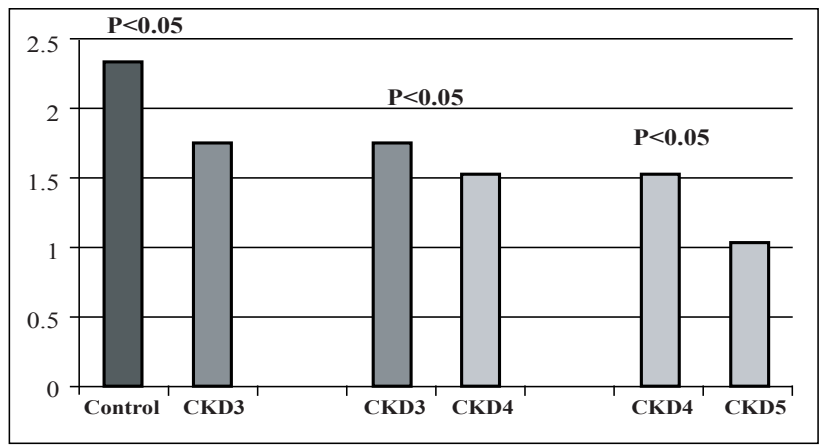

Figure 2: Comparison of serum calcium among different groups

\section{Discussion}

This study was undertaken to estimate GFR in different groups of CKD patients as well as in healthy controls and to correlate these GFR values with s. creatinine and s. calcium. In this study, CKD patients were divided into three groups on the basis of their eGFR values. Pitts et al6 divided the patients into mild renal failure ( $\mathrm{CCr} 40-90 \mathrm{ml} / \mathrm{min}$ ), moderate renal failure ( $\mathrm{CCr} 20-40 \mathrm{ml} / \mathrm{min})$ and end-stage renal failure ( $\mathrm{CCr}<20 \mathrm{ml} / \mathrm{min}$ ). Pitts et al6 demonstrated 
serum calcium level was significantly lower in end-stage renal failure $(\mathrm{CCr}<20 \mathrm{ml} / \mathrm{min})$ group than normal subjects $(\mathrm{P}<0.05)$.

The normal value of serum calcium is $2.12-2.62 \mathrm{mmol} / \mathrm{L}$. In this study, serum calcium of $\mathrm{CKD}^{4}$ and $\mathrm{CKD}^{5}$ were significantly lower than control group $(\mathrm{P}<0.05)$. Therefore, this present findings were consistent with Pitts et $\mathrm{al}^{6}$ observation. It had been originally proposed that hypocalcaemia triggers hyperparathyroidism in early renal failure. Slatopolsky et $\mathrm{al}^{7}$ suggested that phosphate retention and altered vitamin D metabolism contribute to the genesis of hypocalcaemia in uremia. According to Drueke ${ }^{9}$ calcitriol deficiency and phosphate retention together with hypocalcaemia are the main factors involved in the pathogenesis of secondary hyperparathyroidism. Phosphate retention is considered to be a key pathogenic factor, because it decreases calcitriol production and interferes with calcaemic effect of $\mathrm{PTH}^{9-10}$. However, in this study estimation of PTH was not done. In this study, serum calcium had positive correlation with GFR $(r=0.866$, $\mathrm{P}<0.01)$ and negative correlation with serum creatinine $(\mathrm{r}=$ 0.791, $\mathrm{P}<0.01$ ). Pitts et $\mathrm{al}^{6}$ found serum ionized calcium had weak positive correlation with GFR $(\mathrm{r}=0.34, \mathrm{P}<0.01)$. From the present work it is very clear that hypocalcaemia occurs in the advanced stages of CKD patients and is directly related with the degree of renal failure.

\section{Conclusion}

From this study the inference could be drawn that hypocalcaemia occurs in the advanced stages of CKD patients and is directly related with the degree of renal failure. In other words, S. calcium had a positive correlation with GFR and a negative correlation with s. creatinine.

\section{References}

1. National Kidney Foundation (US). About chronic kidney disease; 2002. Available from: http://www.kidney.org/kidneydisease/aboutckd.cfm

2. National Kidney Foundation (US). KDOQI CKD Guidelines; 2002. Available from: http://www.kidney.org/professionals/kdoqi/guidelines_ckd/p4_class_g1.htm

3. Cockcroft DW, Gault MH. Prediction of creatinine clearance from serum creatinine. Nephron 1976;16:31-41

4. Sladen, RN, Endo, E \& Harrison, T: 2-hour versus 22-hours Creatinine clearance in critically ill patients. Anesthesiology, 67: 1013-1016, 1987

5. Morrison, B. Assessment of renal function. Made. Intern. 2(11): 1258-1264, 1986 6. Pitts TO, Piraino BH, Mitro R, Chen TC, Segre GV, Greenberg A, et al. Hyperparathyroidism and 1,25- dihydroxy vitamin B deficiency in mild, moderate and severe renal failure, J Clin Endocrin Metab 1988; 67: 876-81

7. Slatopolsky E, Caglar S, Pennell JP, Taggart DD, Canterbury JM, Reiss E, Bricker NS. On the pathogenesis of hyperparathyroidism in chronic experimental renal insufficiency in the dog. J Clin Invest 1971; 50:492

8. Bricker NS. On the pathogenesis of the uremia state: An exposition of the "tradeoff hypothesis". N Engl J Med 1972; 286:1093

9. Drueke T. The pathogenesis of parathyroid gland hyperplasia in chronic renal failure [Nephrology Forum]. Kidney Int 1995; 48:259-72

10. Rodriguez M, Felsenfeld AJ, Llach F. Calcaemic response to parathyroid hormone in renal failure: Role of calcitriol and the effect of parathyroidectomy. Kidney Int 1991; 40:1063-8

11. Bover J, Rodriguez M, Trinad P, Jara A, Martinez ME, Machad OL, et al. Factors in the development of secondary hyperparathyroidism during graded renal failure in the rats. Kidney Int 1994; 45:953-60 